\title{
STRATEGIES OF ISLAMIC EDUCATION TEACHERS TO INCREASE STUDENTS' INTEREST IN LEARNING AND PRACTICING IN STATE JUNIOR HIGH SCHOOL (SMPN) 1 LANRISANG, PINRANG
}

\author{
St. Wardah Hanafie Das', Abdul Halik², Zulfianah³, Muh Naim \\ 1,3,4 Muhammadiyah University of Parepare \\ Jl. Jend. Ahmad Yani No.Km. 6, Bukit Harapan, Soreang, Pare-Pare, South Sulawesi, Indonesia \\ E-mail:wardahhadas@gmail.com; zulfianah@gmail.com; naimalmandar@gmail.com \\ ${ }^{2}$ State Institute for Islamic Studies (IAIN) Parepare \\ J. Amal Bhakti No.8, Bukit Harapan, Soreang, Parepare, South Sulawsi, Indonesia \\ E-mail:abdulhaliknas@gmail.com
}

\begin{abstract}
Strategies of Islamic Education Teachers to Increase Students' Interest In Learning and Practicing in State Junior High School Lanrisang (SMPN) 1 Lanrisang, Pinrang. This study aims to examine strategis used by Islamic education teachers to increase learning interest and practice of Islamic education on students of SMPN 1 Lanrisang, Pinrang. Increasing interest to study and practice Islamic education course on public school's students is important for academics and practitioners. Therefore, a proper design of learning strategies is needed to increase interest and practice of the course. This article employed a qualitative method with a phenomenological approach by looking at the phenomena in the field. The results of interview and data analysis show some factors causing students' low interest in learning Islamic education, including students' low awareness during the learning activity, memorization system and indoctrination, tight schedule, national exam, a monotone learning strategy, and lack of family support. In addition, students seldom perform worship of mahdhah, while they often perform mu'âmalah. To increase the learning interest, the teachers of SMPN 1 Lanrisang used specific learning strategies such as lecture, debate, role-play, simulation, demonstration, contextual-based, problem-based, habituation and togetherness.
\end{abstract}

Keywords: Islamic education teachers'; strategy; learning interest; Islamic education.

\begin{abstract}
Abstrak: Strategi Guru Pendidkan Agama Islam dalam Meningkatkan Minat Belajar dan Pengamalan Pelajaran Agama di SMP Negeri 1 Lanrisang Pinrang. Tujuan dari penelitian ini adalah untuk mengetahui strategi yang dilakukan oleh guru Pendidkan Agama Islam (PAI) dalam meningkatkan minat belajar dan pengamalan pelajaran PAI pada siswa di SMP Negeri 1 Lanrisang, Pinrang. Meningkatkan minat belajar PAI dan pengamalannya pada siswa di sekolah negeri umum menjadi perhatian bagi kalangan akademisi dan praktisi, sehingga diperlukan adanya desain strategi pembelajaran yang tepat dan benar agar dapat memicu peningkatan minat belajar PAI dan pengamalannya. Artikel ini merupakan penelitian kualitatif dengan pendekatan fenomenologis dengan melihat fenomena yang terjadi di lapangan. Berdasarkan hasil analisis data wawancara terhadap informan, peneliti menemukan bahwa penyebab dari masih rendahnya minat belajar PAI siswa adalah karena beberapa faktor, yaitu rendahnya kesadaran siswa terhadap pembelajaran PAI, sistem hafalan dan indoktrinasi, padatnya jam pelajaran, ujian nasional, penggunaan strategi pembelajaran yang monoton, dan kurangnya dukungan dari keluarga. Selain itu, siswa lemah dalam amalan yang bersifat mahdah, sedangkan dalam bidang mu'âmalah cukup tinggi. Penelitian ini menemukan bahwa strategi guru PAI di SMPN 1 Lanrisang dalam meningkatkan minat belajar dan pengamalan ajaran Islam siswa adalah dengan cara ceramah, debat, role play, simulasi, demonstrasi, berbasis kontekstual, berbasis masalah, keteladan, pembiasaan, dan kebersamaan.
\end{abstract}

Kata kunci: guru Pendidikan Agama Islam; strategi; minat belajar; pengamalan Pendidikan Agama Islam.

\section{Introduction}

Each student has unique characteristics, and the learning process should consider individual difference to change student's behavior, either in cognitive, affective, or psychomotoric way.

1 Yohanes Joko Saptono, "Motivasi dan Keberhasilan Belajar Siswa”, RegulaFidei Vol. 1, No. 1, Maret 2016, p. 192. 
Each student has their own level of intellectuality, absorption, interest and motivation, learning style and tendency. This personal difference could become a barrier during learning process since it should accommodate all differences in one learning forum to achieve the expected goal. Such condition forcesthe teacher to make a learning design, particularly learning strategy.

The role of learning strategy has implication for learning effectivity. ${ }^{2}$ Strategy means choices of education pattern taken to achieve a particular goal effectively. ${ }^{3}$ Learning design begins with a good curriculum concept that becomes a reference to conduct an academic activity in school. A good curriculum does not guarantee students' achievement if it is not supported by a proper learning strategy. ${ }^{4}$ Curriculum has some learning goals in accordance with the materials taught to students. This curriculum needs operational interpretation that meets students' condition as the subject and object of education. ${ }^{5}$ The harmony of learning design and students' condition will ease the transmission process during class activity. A boring learning activity will lead to learning ineffectivity. ${ }^{6}$

Islamic Education in public school is a core curriculum that must be followed by Muslim students. The strategy in Islamic education system purpose to shape an Islamic thinking (aqliyah Islâmiyyah) and behavior (nafsiyyah Islâmiyyah), as well as to equip students with knowledge of life, ${ }^{7}$ weaving (skills), writing and reading, taking care of sick person (medication and nursing). Islamic education course in school can be applied through an effective learning

${ }^{2}$ Buto, Zulfikar Ali. "Penerapan Strategi Pembelajaran Mahasiswa Prodi Pendidikan Agama Islam pada Sekolah Tinggi Agama Islam Negeri (STAIN) Malikussaleh Lhoksoumawe", Jurnal Tarbiyah Vol. 24, No. 1, January-June 2017, p. 183.

3 Mustofa, Muhammad Khairil. "StrategiPendidikan Islam Nabi Muhammad Saw.", Jurnal Studi Islam Vol 10, No. 2, December 2015, p. 94.

${ }_{4}$ Zamroni. Pendidikan Masa Depan, (Yogyakarta: Bigraf Publising, 2010), pp. 74-75.

5 Junaidah, "Strategi Pembelajaran Dalam Perspektif Islam" Al-Tadzkiyyah: JurnalPendidikan Islam Vol. 6, May 2015, p. 120.

${ }^{6}$ Syaiful Bahri Djamarah, dan Zain Aswan. Strategi Belajar Mengajar (Jakarta: Rineka Cipta, 2010), p. 7.

7 M. Sobry, "ReaktualisasiStrategiPendidikan Islam: Ikhtiar Mengimbangi Pendidikan Clobal”, Ulumuna Jurnal Studi Keislaman, Vol. 17, No. 2, December 2013, p. 83 strategy. ${ }^{8}$ This strategy can be categorized into two: (1) exposition-discovery learning and (2) group-individual learning ${ }^{9}$ and can be using in Islamic education according to purpose, content, the student condition and available resources.

Based on the explanation above, teacher is required to develop themselves to keep being creative and innovative during the learning process that is oriented on increasing students' learning interest. Teacher is expected to have creativity and innovation when arranging learning strategy..$^{10}$ Several references have offered this strategy. Teacher only has to choose the strategy that corresponds to goals, materials, students, media, environment and evaluation system. Teacher's ability to design learning strategy has implications for goals' achievement in effective and efficient ways."

Students have quite complex challenges during in-class learning. Students prefer that their teachers could put jokes, utilize information and communication technology and employ problem-based and contextual strategy during learning activity. Learning orientation aimed at students and learning strategy must be based on students' situation and condition. A proper learning strategy can trigger students' learning interest, particularly in Islamic Education course. Islamic Education course also has challeges for students, including memorization-oriented, lack of facilities and learning burden. ${ }^{12}$ Those conditions are also faced by students of SMPN 1 Lanrisang Pinrang.

In addition to teacher's learning strategy, student's interest becomes an important factor to achieve learning goals. In this case, Crow \& Crow states that interest can be related

\footnotetext{
${ }^{8}$ Abdurrahman al- Bagdadi, Sistem Pendidikan Dimasa Khilafah Islam (Bangil Jatim: Al-Izzah, 1996), p. 44.

9 Wina Sanjaya, Strategi Pembelajaran Beroreantasi Standar Proses Pendidikan (Jakarta: Kencana, 2008), p. 127.

${ }^{10} \mathrm{M}$. Shabir U, “Kedudukan Guru Sebagai Pendidik: Tugas danTanggungJawab, Hak dan Kewajiban, dan Kompetensi Guru", AULADUNA Vol. 2, No. 2, December 2015, pp. 221-232

${ }^{11}$ W. Gulo, Strategi Belajar Mengajar (Jakarta:PT Grasindo, 2002), p. 4.

12 Muhammad Ishak, Syahidin, dan Saepul Anwar, "Pengaruh Minat Belajar dan KedisiplinanTerhadap Prestasi Belajar PAl”, TARBAWY Vol. 3, No. 2, 2016, p. 121.
} 
to the motive that drives us to tend and feel interested in people, things or activities, or effective experiences stimulated by the activities themselves. In other words, interest can be the cause of activities and participation in activities. ${ }^{13}$ Interest means a tendency and high enthusiasm or a great desire for something. ${ }^{14}$ Based on this interest, someone will make every effort to master something that interests him. Interest can be the cause of the emergence of activities and participation. Interests have elements of cognition (knowing), emotions (feelings), and monation (will). ${ }^{15}$ Slameto argued that children's interest could be raised with two things, namely (1) giving attention and (2) incentives (gifts).$^{16}$ Learning interest leads to the process of intelligence, with indicators of the ability to solve problems and create products of cultural value. ${ }^{17}$

In addition to allowing concentration of mind, interest leads to excitement in learning efforts. Cheerfulness will increase the power of one's learning abilities. ${ }^{18}$ It also helps him not easily forget what he has learned. Learning interest can be measured through four indicators as mentioned by Slameto, namely learning interest, attention in learning, motivation to learn and knowledge. ${ }^{19}$ Thus, the teacher should provide motivation in learning by: (1) encouraging students to learn, (2) giving a concrete explanation about what can be done at the end of teaching, (3) giving rewards to achievements that can stimulate more

${ }^{13}$ L. Crow \& Crow,Psikologi pendidikan, (Yogyakarta: Nur Cahya, 2009), trans Education psykologi 1, pp. 302-303

${ }^{14}$ M. Syah, Psikologi Pendidikan dengan Pendekatan Baru, (Bandung: PT RemajaRosdakarya, 2011), p. 133.

${ }^{15}$ Abrurrahman Abror, Psikologi Pendidikan, (Jogjakarta: Tirta Wacana Jogja, 1993), p. 112.

${ }^{16}$ Slameto, Belajar dan Faktor-faktor yang Mempengaruhinya, (Jakarta: Rineka Cipta, 2010), p. 121.

${ }^{17}$ Ariani Syurfah, Multifle Intelligences for Islamic Teaching (Panduan Melejitkan Kecerdasan Majemuk Anak Melalui Pengajaran Islam, (Bandung: Syamil Publishing, 2007), pp. vii.

${ }^{18}$ Khoirul Anam, "Pengaruh Media PembelajaranTerhadap Minat Belajar Siswa Pada Mata Pelajaran PAI Di SMP Bani Muqiman Bangkalan", Tadarus: Jurnal Pendidikan Islam Vol. 4, No. 2, 2015.

${ }^{19}$ See. Siti Nurhasanah \& A. Sobandi, "Minat Belajar Sebagai Determinan Hasil Belajar Siswa", Jurnal Pendidikan Manajemen Perkantoran, Vol. 1, No. 1, Agustus 2016, pp. 135142. achievement in the future, (4) forming good learning habits. ${ }^{20}$

The interest in studying Islamic education for students has not matched the expectations of teachers and schools. This can be seen in aspects of learning in the classroom and outside the classroom. The student's interest in learning Islamic education is caused by internal and external factors. Internal factors are more about students' willingness and awareness of the lesson, and their willingness to practice them. External factors include learning facilities, classroom environment, and the teacher's ability to design Islamic education learning strategies. The teacher's ability to choose and apply the strategies in the classroom has implications for student's response and participation in learning. Thus, the teacher has a high responsibility for the interest in learning Islamic education, especially at SMPN 1 Lanrisang, Pinrang.

The discourse above is very interesting to study, especially in answering the question of interest in learning Islam and the practice of Islamic teachings for students of SMPN 1 Lanrisang, Pinrang.This study also examines the strategies of Islamic education teachers in increasing student's interest in learning and practicing Islamic education in SMPN 1 Lanrisang, Pinrang.

\section{Method}

This research was a qualitative study using the phenomenological approach. Data collection techniques in this study were observation, interviews, documentation, and triangulation. ${ }^{21}$ Observation was conducted in a participatory manner, where researchers directly participated in Islamic education learning activities in classroom, in-depth interviews with the teachers and students regarding learning strategies. Literature study was carried out by examining school's learning materials and academics of Islamic Education

${ }^{20}$ Hamsah B. Uno, Profesi Kependidikan: Problema, Solusi, dan ReformasiPendidikan di Indonesia, (Jakarta: Bumi Aksara, 2009), $4^{\text {th }}$ printing, p. 23.

${ }^{21}$ See. Sugiyono, Metode Penelitian Kombinasi (Mixed Methods), (Bandung: Alfabeta, 2011), $1^{\text {st }}$ edition, p. 305. 
course. Data triangulation was employed to connect the data obtained through different techniques. To explore the results of participant observation, researchers also collected data from two informants who were Islamic education teachers at SMPN 1 Lanrisang. The researcher tried to explore the process of learning activity and others.

The research instrument was the authors themselves as in other qualitative study. The authors "validated" themselves by making consultation with experts about the preparation, data, data observation and data saturation (complete). The process of data collection was carried out through observations, interviews, documentation and triangulation. ${ }^{22}$ The observations were conducted in a participative way as the authors joined in the process of Islamic education learning activity, had indepth interviews with the course's teachers and students related to the learning strategy, performed literature study by examining learning materials and academics record of Islamic Education conducted at school, as well as connected the obtained data through a varied techniques of triangulation.

The data analysis technique in this study referred to Moleong's opinion that, "data analysis is the process of organizing and sorting data into patterns, categories, and basic description units so that themes can be found and the work hypothesis formulated as suggested by the data. ${ }^{23}$ Data process and collection could be done by aggregating, organizing, and classifying data into manageable units. Aggregation was the process of abstracting specific things into general things in order to find a general pattern of data. Data can be organized chronologically, categorically or included in typology. Data analysis was carried out since the researcher out in the field, during data collecting and after all data was collected or after completion of data collecting in the field. In simple terms, data were analyzed using patterns of data

${ }^{22}$ Sugiyono, Metode Penelitian Kombinasi..., p. 309

${ }^{23}$ Lexy J. Moloeng, Metodologi Penelitian Kualitatif, (Bandung: PT. RemajaRosdakarya, 2004), pp. 280- 281. collection, data reduction, data presentation, and conclusion drawing.

\section{Student's Learning Interest in SMPN 1 Lanrisang, Pinrang}

Student's interest in learning Islamic education is a focus in this study. Based on the results of observations made by the author, most students showed low interest in participating in the learning activities. For example, there were students who talked to friends, slept in class, accessed facebook and played games through mobile phones. This indicated that students have a low learning interest during the course. Based on this condition, Muhammad Firman, the Head of SMPN 1 Lanrisang, in his interview said that the condition of students during Islamic education course varied, including those who enjoyed the subject and were happy with general subjects. ${ }^{24}$

From the information above, the principal acknowledged that some students had not shown respect for Islamic education subject at school. Many students lacked response to the course as they showed excitement when they left the classroom after the learning process as if they were free from stress. This indicates that many students feel forced or afraid of the teacher and the principal. This condition seems to have escaped the attention of the principal. Furthermore, Bachtiar, teacher of Islamic education subject, stated that students' attention to the course was quite good. They follow and pay attention when the teacher explains. Similarly, if the teacher gives the assignment, they always work on time even though there are a small number of students not paying attention and not doing the assignment on time. 25 There is a difference of opinion between the explanation of the teacher and the principal.

Based on the results of observations, the researchers found that there were only a few

${ }^{24}$ Interview with Muhammad Firman, Head of SMPN 1 Lanrisang, May 5, 2017.. I; Bandung: Alfabeta, 2011), p

25 Interview with Bachtiar, Islamic education teacher, May 6, 2017. 
students were happy with Islamic education course, especially in memorizing lessons that made students bored, even more so when the subject took place in the last hours of school, because students were sleepy and tired. Student's interest in learning Islamic education subject can be realized if the learning process can run effectively and optimally. A good and conducive learning process can provide good understanding and practice to students, so the teacher must choose a strategy that is in accordance with the subject matter. Based on this, Asmaul Husnah, a student, stated that her ability to understand the subject is still changing frequently. Students are able to accept or understand quickly and slowly in understanding subjects or material delivered by the teachers depending on the teacher's strategy in teaching the course. ${ }^{26}$

Based on the field observations, the teacher seemed inconsistent in applying learning strategies that attracted interest to students. Sometimes the teacher looks very ready to teach with thorough preparation and even actively uses Liquid Crystal Display (LCD) media. However, there are times when teachers seem unprepared to teach by only relying on makeshift teaching materials or just repetition without careful preparation and not using LCD media. Based on the observations, students gave more respond to the lesson conducted by teachers with careful preparation and using LCD media than teachers who have no teaching preparation at all.

The results of observation found that the lack of students' interest in Islamic education course was because students were often affected by the high standard of assessment on subjects tested on national examinations. Therefore, it makes students more focus on subjects that are considered more difficult, especially science and social studies. Students assume that Islamic education subject has often been studied even outside of school. Based on this condition, Bachtiar revealed that this

${ }^{26}$ Interview with Asmaul Husna, student of SMPN 1 Lanrisang , May 6, 2017. was a big challenge for the school and the family. This means that there is a big and heavy role in providing education and teaching as well as monitoring the learning process of students both at school and at home. Good communication and cooperation from all parties is needed. ${ }^{27}$

The above statement is in line with the results of observations that Islamic education teachers seemed overwhelmed to provide the lesson to students if there was a lack of support from the family. Some students who are known to have a religious family background tend to have a high interest in learning the course in class. Family is the first and foremost place of education, so it has a big influence on children's development. However, students from families who lack understanding in religion have a low interest in studying Islam. Based on this, in an interview with school counselor, Haruna, revealed that the family is the most important supporting factor in increasing the interest in learning and practicing the teachings of Islam for students because the role and attention of parents is very large in guiding and directing the education of their children. ${ }^{28}$

The results of observations indicated that schools always involve school committees in certain activities at school. However, parents' participation in school activities such as teacher and parent meetings, or other meetings, rarely attracts parents to attend the event. When there is a letter from the counselor confirming the character of the child at school, it appears that the parents of the student are not responding quickly to the confirmation. Families have a big role in encouraging their children (students) to learn Islamic Education at school. Students have more time at home so that if it is irrelevant between the learning at school and parents 'attention at home, it will have a psychological impact on students' interest in learning Islamic education.

Based on the results of observations and

${ }^{27}$ Interview with Bachtiar, Islamic education teacher, May 10, 2017.

${ }^{28}$ Interview with Haruna, School counselor, June 2, 2017. 
interviews above, it was also found in the Islamic education teacher's document that almost every Islamic education course in school was remedial learning because there was no Minimum Completion Criteria (KKM). There were around five to ten students who were remedial participants. It can be concluded that student's interest in learning Islamic education at SMPN 1 Lanrisang has not shown any encouraging indicators.

\section{Implementation of Islamic Teaching for Students of SMPN 1 Lanrisang, Pinrang}

The implementation of Islamic teaching in students reflects the learning interest of Islamic education in class. Based on document analysis, it was revealed that Islamic education materials based on class classification were as follows:

$\ln 7^{\text {th }}$ grade, the Islamic subject delivered is about religious-based activity such as worship, mu'âmalah, and ethics. Worship encompasses: obligatory fasting, Sunnah fasting, obligatory prayer, and Sunnah prayer; mu'âmalah includes possession and zakah; ethics are addreesed to parents, to teacher, and to human beings.

In $8^{\text {th }}$ grade, the difference of subjects taught more varied,including fasting, Islamic demand of right and mandatory for citizen, animal sacrifice (qurban), and the spread of Islam in Indonesia and during Bani Abasiyah period. The fasting topic explains about compulsory and Sunnah fasting, prohibited days of fasting, people who able to fasting, and fasting value.

Unlike lower grade, $9^{\text {th }}$ grade topics are Hadith of faithful to God; behavior among human beings; Quran surah az-Zumar [39], al-Baqarah [2]; and great sin.

The subject materials mentioned are according to class classification that subsequently becomes indicator for students about Islamic subject implementation. Regarding to this, Hasnidar, $7^{\text {th }}$ grade student, asserted that most of her friends in SMPN 1 Lanrisang are good enough in implementing Islamic subjects. They are aware of their obligation to perform the values of Islamic subject, such as morality to teachers and fellow students, fasting, lazy to pray together, and others. ${ }^{29}$

The observation results indicated that student have to be faithful in implementing Islamic values since the school is strict and discipline. For those who are unwilling to pray together will be handled by headmaster or school counselor to be advised and warned. Students who violate the rule will be punished, according to violating level of the student. The implementation of Islamic subject related to good deeds in daily activities is carried out by the followings:

\section{(a) Prayer Implementation}

Salat is mandatory for Muslim, regardless the gender and age, as long as they can distinguish the good and bad. Adversely, it is inessential for them who have not met the required age, eventhough Islamic law states that 7 year-old-child is suggested to pray. Therefore, Hardiansyah, $8^{\text {th }}$ grade student, asserted that the students are advised to perform prayer by the teachers. He was lazy at first, but then it becomes habitual activity. ${ }^{30}$ Another informant, Muhammad Nasir, said that they perform five prayers a day because of teacher's guidance, especially from Islamic subject teacher. Eventhough shubuh is performed after dawn, at 6 o'clock because he woke up late. ${ }^{31}$

Prayer implementation conducted in SMPN 1 Lanrisang, Pinrang, is dhuhur prayer at noon that is performed together in mushalla (prayer room) after school, followed by supervision of homeroom teacher of each class. Meanwhile, Asar, Maghrib, Isya, and Shubuh are performed at home with parents' control. Parents are also expected to be cooperative in supporting schools' program by monitoring children's prayer activity since five prayers needs to be a habit. Bahtiar, an Islamic subject teacher, said that to support school programs of Islamic implementation

\footnotetext{
${ }^{29}$ Interview with Hasnidar, $7^{\text {th }}$ grade student, May 5, 2017. ${ }^{30}$ Interview with Hardiyansah, $8^{\text {th }}$ grade student, June 2, 2017.

${ }^{31}$ Interview with Muhammad Nasir, $8^{\text {th }}$ grade student, June 13, 2017.
} 
habitual,the school and parents must cooperate so that the purpose of the program can be achieved. ${ }^{32}$

According to field observation, the students are difficult to perform prayer together, particularly at school. One of the causes is a small room facility. As a result, the room only accommodates limited student to perform prayer together, while the Muslim students reach to 1000 students.

\section{(b) Habit of Fasting}

Fasting is one of Islamic practices, either Ramadhan fasting or sunnah fasting. Based on this theory, Nurlinda as a student, believes that entering Ramadhan is a pleasant moment for her. She also realizes that Ramadhan fasting is a duty. She even said that besides Ramadhan fasting, she also learns to do Sunnah fasting eventhough it's not routine yet. 33

The practice of fasting is highly emphasized for students of SMP Negeri 1 Lanrisang Pinrang. In addition to their duty, it is explained that fasting has many benefits, including curing disease. In its practice, the school works together with students' parents. In an interview, Akirah, a teacher in SMP Negeri 1 Lanrisang Pinrang, said that the students should be provided with knowledge of fasting, and the parents must assist the practice. The school controls the practice through Ramadhan activity book, while the parents will monitor and complete the book.

The school gives much concern regarding the practice of fasting. However, based on field observation, several male students were found eating in secret because they were not fasting. Student who did not fast were also the students who were lazy to pray in mosque. However, their Ramadhan activity book were completed, so it could be concluded that some students who did not practice Islamic teaching were those who often made troubles in school. ${ }^{34}$

32 Interview with Bachtiar, Islamic education teacher, June 7, 2017.

${ }^{33}$ Interview with Nurlinda, $8^{\text {th }}$ grade student, June 10, 2017.

34 Interview with Akirah the teacher, 6 June 2017.

\section{(c) Habit of Reading Daily Prayer}

Islam always encourages its follower to pray before doing daily activities in order to be blessed by Allah Swt. Praying is also practiced by student when they are entering and leaving class in school. In this case, praying in SMPN 1 Lanrisang has become habit. 35

In order to prove the statement, classroom observation showed the same result. It was found that the students always pray before starting every lessons. Praying is not only practiced during Islamic education course, but aslo in every lesson in school. In order to validate this statement, Ulfa as a student in IX class, revealed that when entering every classroom, the students never forget to pray together before starting lesson, because praying is a reflection of Muslim before starting their activities.

Based on the field observation, students are regularly praying if teacher or headmaster leads the praying. If students are out of teacher's observation such as in canteen, they rarely pray before eating. They even eat by standing or drinking using left hand. The behaviour are still considered as ordinary in school.

\section{(d) Habit of Reading the Quran}

Learning Quran for every Muslim is an obligation. First step to learn Quran is by knowing how to read it. Reading the Quran is also recognized as Murattal. In terms of the habit of reading the Quran, SMPN 1 Lanrisang requires students to carry out memorization of short letters or Juz 'Amma. In addition, teachers are also always strived to improve the quality in the process of teaching and learning activities so that students can accomplish maximum achievement.

The results of observations at SMPN 1 Lanrisang, Pinrang showed that Islamic Education class teachers worked hard to improve students' ability to read Quran properly, because in each evaluation results showed less than the optimal results, such as the high percentage of

35 Interview with Melda, Islamic education teacher, June 14, 2017. 
students who did not reach standard mark in Islam subjects. This is because in reality there are some students who are still not maximally participating in short memorization activities, and lack technique mastery and memorizing in reading the Quran. For this reason, Islam education class teachers at SMPN 1 Lanrisang, Pinrang pulled out several efforts to improve the ability of students to read Quran by holding the habit of Quran recitation every friday before the learning process.

\section{e) Habits of Practicing in Social Field}

The practice of Islamic education in addition to the practice of praying to Allah Swt also contains worship in all aspects of life. In this case, students understand and practice Islamic education by the practice of charity. Every friday, recitation of surah Yâsîn and Quran in general are held. The practice of Islamic education in school is coordinated by teachers that include social service activities, charity for disaster victims, visitation and charity for friends, who are sick both at home and in the hospital. The principal of SMPN 1 Lanrisang, Muhammad Firman said that deeds are done for every family either from a teacher or student who was sick, died, become victim of a disaster, mutual cooperation activities and so on; students always participated in this matter. The principal and fellow teachers teach students about the importance of helping each other, because it contains the value of education and habituation to students. It is also expected that in the future they will use these kindness in their social life. ${ }^{36}$

The results of real-life observations showed that the students' social practice is quite active. ${ }^{37}$ Every time a disaster happens, students always participate in setting aside their allowance to share donations. In this regard, it can be said that the practice in the social field in SMP 1 Pinrang students is quite good, but it still has to be used as an actual habit because so far the

${ }^{36}$ Interview with Muhammad Firman, Head of SMP 1 Lanrisang, June 15, 2017

37 Sugiyono, Metode Penelitian Kombinasi..., p. 309 act of helping is done because of the instruction from the teacher.

\section{Strategies of Islamic Education Teachers to Increase Students' Interest In Learning and Practicing in SMPN 1 Lanrisang, Pinrang}

The teacher has responsibility in developing learning interest and practice of Islamic education for students. The success or failure of students always becomes the spotlight to judge the competence of Islamic education teachers. Therefore, the learning strategy by the subject teachers becomes a demand that must be developed continuously to achieve the learning objectives that have been set by the teachers. Based on this fact, one of the informants from the teacher stated that the learning strategy is always used in SMPN 1 Lanrisang, Pinrang because it will support the success in learning process for the student, with the existence of a good learning strategy. The teacher realizes that educating students without using appropriate and effective learning strategies will only result in failure in the teaching and learning process. ${ }^{38}$

The success of a learning strategy can be determined from the success of students in achieving the learning objectives. The observation showed that Islamic education teachers have tried to implement learning strategies in the classroom, but there is no guarantee that students would respond to what has been expressed by teachers even though the learning strategy is designed to consider aspects of the objectives expected to be achieved. The teachers have understood the principles in choosing and defining the class learning strategies that demand to be creative and innovative to create effective learning in achieving goals. Based on observations in the field, the subject teachers seemed to use learning strategies that varied between the first and subsequent meetings. At times, the teachers would do simulations, demonstrations,

\footnotetext{
${ }^{38}$ Interview with informants, July 8, 2017
} 
or even just lectures. In addition, the Islamic education teacher, as acknowledged by Bachtiar, often had sorted out the mastered learning strategies such as cooperative learning, problem based learning, and contextual teaching for the learning process. The strategy used is tailored to the goals, material, and situation of students. ${ }^{39}$

Based on the results of observations, it was shown that the subject teachers sometimes used strategies of cooperative learning type Jigsaw, problem-based learning, and Constextual Teaching and Learning (CTL) strategies. When the teacher uses this strategy, students are seen actively participating in learning because students feel the strategy is in line with their desires and learning power. The strategy is used if the circumstance is truly ready and there is no additional business in schools such as committee event gathering or out of town works. The strategies used by the teacher are quite impressive and interesting for students. This is as revealed by Abdullah, a grade VIII student, that Islamic education teachers are often being pleasantly interesting when the learning strategies used are not boring. To make stimulating learning variations, the teachers also use group-learning strategies by Jigsaw technique..$^{40}$

From the observation, students were more active when Islamic Education teacher applied cooperative learning and problem-based learning. They were passive when the teacher did not use any learning strategy. As the teachers fully aware of this condition, they try to improve their teaching capacity and competencies in pedagogy and professional. One of the efforts is to participate in a teacher forum such as Musyawarah Guru Mata Pelajaran (MGMP) PAI in Pinrang. Colleagues in SMPN 1 Pinrang often idolize it in one aspect of the course.

Students' satisfaction and high interest in learning the subject is one main target expected by teachers. However, learning strategy of Islamic education subject in classroom cannot guarantee to increase the interest of students.

39 Interview with Bachtiar, Islamic education teacher, July 18, 2017.

${ }^{40}$ Interview with Abdullah, $8^{\text {th }}$ grade student, June 9, 2017.
The teacher understands that the respond of students are vary. Because of that, learning strategy with cooperative learning or problembased learning is not quite effective to be implemented in teaching. Sometimes, learning strategy of lecture, study group, assignment, discussion or debate, would make a good choice to be applied in the class. ${ }^{41}$

According to the observation, students were enthusiastic when the teacher applied one of the above strategies. Students enjoyed the subject because it was dynamic and gave chance for them to fully explore and improve on their own. Sometimes, students did not really pay attention to the material explained by the teacher; rather they were just simply enjoying the way the course was being delivered. The strategy above is taught in a workshop held by Board of Education or delivered by Non Goverment Organization (NGO) United States Agency for International Development (USAID).

The observation showed that the teacher had tried to conduct Islamic education course using the correct strategy and method, but it also has to be supported by social competency and characteristic. If the teachers cannot be a good example for students, or they cannot interact well with them, then the students will not feel obligated, or willing to implement the teaching. For example, when an Islamic education teacher did not perform a congregation prayer, some of students were not going to do it.

Students work hard if there is assignment given to them. Usually it is distributed and performed in-group. Every group will work hard to compete with other groups. It seems that the teacher often give appreciation for the best group who gives their best during the assignment. On the other hand, students will likely be dependent towards the teacher. If the teacher is active, then the students will too.

Outside the school hours, students do not pay attention to the implementation of Islamic education course. The teaching process is not focused solely in the classroom, but in the

${ }^{41}$ Interview with Bachtiar, Islamic education teacher, July 19, 2017. 
school's environment. The teacher motivates the students to learn diligently and to apply Islamic teaching sincerely. The result of observation showed that the teacher always get closer to students in break time, throwing a joke, giving advice whether it is in schoolyard, school's canteen, or when they play table tennis together. The school and other teachers also support Islamic Education teacher because they all have the same goal and commitment in motivating students and applying Islamic values in the school.

Learning strategy of Islamic education subject has to be developed, especially for the course offered in middle school. It is hard considering the internal and external factors. Students' interest in learning Islamic education in SMPN 1 Lanrisang Pinrang is varying. The number of students who want to learn further about the course is outnumbered by those who do not have any interest in it. This indicator can be shown by the number of students taking remedial test. This indicates that their score does not meet the minimum grade. The lack of family support/ attention could also be another cause.

As for the awareness in learning and implementing Islamic values, researcher found students who were fully aware and pious in doing it, yet there were some who did not really care if he/she did it or not. The research showed that students who had low interest in learning Islamic education were the students who had low awareness in applying Islamic values to their surrounding, such as congregation prayer, fast, and recite prayers and Quran. However, every student showed a great awareness in social matter (helping others, being good to others). It can be said that the students demonstrated a good relationship with fellow human beings (students, teachers, etc.), but they demonstrated a lacking awareness in their relationship with God.

Study interest in Islamic education subject and the implementation of Islamic teaching are part of the implications of learning strategy for the course in classroom. Islamic education teacher applies strategy of cooperative learning, problem-based learning, and contextual teaching and learning, and uses various methods as follows: lecture, assignment, discussion, study group, simulation, and demonstration among others to show the response of the students. To apply one learning strategy, it is always followed by a few learning methodologies. Thus, the school fully supports the improvement in increasing students' interest and implementation of Islamic education subject by becoming the good example, making the students get accustomed to Islamic values and ritual, and giving reward and punishment at school. Those things mentioned are the strategy from Islamic education teacher to develop students' interest and Islamic teaching implementation in SMPN 1 Lanrisang, Pinrang.

Islam highly appreciates all strategies used in Islamic education teaching. The basic of Islamic education teaching compromised with the basic of religiosity, biology, psychology, and sociology. ${ }^{42}$ To formulate the proper learning strategy, there are factors that need to be taken into consideration that covers the purpose of Islamic teaching, students, situation, facilities, and teacher's characteristic. ${ }^{43}$ Before applying the learning strategy in classroom, teacher has to have a good grasp of Islamic teaching purpose; student's background like ideals, talents, nature, interests, preferences, and others; situation of the surrounding (inside and outside classroom); learning facilities availability, and teacher's ability and capability.

\section{Conclusion}

Based on the research and discussion above, it can be concluded that students of SMPN 1 Lanrisang, Pinrang lacked of learning interest. It happened because of some factors, including the students' low awareness of Islamic education subject, indoctrination and memorization concept, National Exam, a boring teaching strategy, packed school hours, and less support from the family.

${ }^{42}$ See Ramayulis \& Samsu Nizar, Filsafat Pendidikan Islam Telaah SistemPendidikan dan Pemikiran Para Tokohnya (Jakarta: Kalammulia, 2009), p. 216

43 Winarno Surakhmad, Dasar dan Tehnik Interaksi Mengajar dan Belajar, (Bandung: Tarsito, 1973), pp. 19-93. 
The implementation of Islamic teaching as done by students of SMPN 1 Lanrisang, Pinrang was considered good. They performed congregation prayer, fasted in month of Ramadhan, recited prayers and Quran, and helped others. However, there were students who did not do the things said above, whereas in muamalah subject like social service, all students displayed the same attitude. To attract students' interest, Islamic education teacher could implement learning strategy such as cooperative learning Jigsaw type, problem-based learning, and contextual teaching and learning. These strategies are always followed by several methodologies such as lecture, assignment, study group, and discussion. In order to obtain students' interest in learning Islamic education, teacher must develop four competencies, which include pedagogy, professional, social, and characteristic. To successfully establish such condition, the teacher needs support from principal, other subject teachers, and staffs.

\section{References}

Abror, Abdurrahman, Psikologi Pendidikan. Vol. 4, Yogyakarta PT. Tiara WacanaYogya, 2003. Anam, Khoirul, "Pengaruh Media Pembelajaran Terhadap Minat Belajar Siswa Pada Mata Pelajaran PAI di SMP Bani Muqiman Bangkalan", Tadarus: Jurnal Pendidikan Islam Vol. 4, No. 2, 2015.

Bagdadi, Abdurrahman Al-, Sistem Pendidikan di Masa Khalifah Islam.Vol. 1. Surabaya: AlIzzah, 1996.

Buto, Zulfikar Ali, "Penerapan Strategi Pembelajaran Mahasiswa Prodi Pendidikan Agama Islam pada Sekolah Tinggi Agama Islam Negeri (STAIN) Malikussaleh Lhoksoumawe", JURNAL TARBIYAH Vol. 24, No. 1, JanuaryJune 2017.

Crow, L. \& Crow, Psikologi pendidikan, Trans. Yogyakarta: Nur Cahya, 2009.

Djamarah, Syaiful Bahri, dan Zain Aswan, Strategi Belajar Mengajar, Jakarta: Rineka Cipta, 2010. Gulo, W, Strategi Belajar Mengajar. Jakarta: Grasindo, 2002.

Ishak, Muhammad, Syahidin, dan Saepul Anwar, "Pengaruh Minat Belajar dan Kedisiplinan
Terhadap Prestasi Belajar PAI", TARBAWY Vol. 3, No 2, 2016.

Junaidah, "Strategi Pembelajaran Dalam Perspektif Islam" Al-Tadzkiyyah: JurnalPendidikan Islam Vol. 6, May 2015.

Moloeng, Lexy J, Metodologi Penelitian Kualitatif.

Bandung: PT. Remaja Rosdakarya, 2004.

Mustofa, Muhammad Khairil, "Strategi Pendidikan

Islam Nabi Muhammad Saw.", Jurnal Studi Islam Vol.10, No. 2, December 2015.

Nurhasanah, Siti\& A. Sobandi, "Minat Belajar Sebagai Determinan Hasil Belajar Siswa", Jurnal Pendidikan Manajemen Perkantoran Vol. 1, No. 1, August 2016.

Peraturan Pemerintah Republik Indonesia No.

32 Tahun 2013 tentang Perubahan Atas

Peraturan Pemerintah Republik Indonesia No. 19 Tahun 2005 tentang Standar Nasional Pendidikan.

Ramayulis \& Samsu Nizar, Filsafat Pendidikan Islam Telaah Sistem Pendidikan dan Pemikiran Para Tokohnya. Jakarta: Kalammulia, 2009. Sanjaya, Wina, Strategi Pembelajaran Beroreantasi Standar Proses Pendidikan. Jakarta: Kencana, 2008.

Saptono, Yohanes Joko, "Motivasi dan Keberhasilan Belajar Siswa”, Regula Fidei Vol. 1, No. 1, March 2016.

Shabir U., M, “Kedudukan Guru Sebagai Pendidik: Tugas dan Tanggung Jawab, Hak dan Kewajiban, dan Kompetensi Guru", AULADUNA Vol. 2, No. 2 December 2015.

Slameto.Belajar dan Faktor- faktor yang Mempengaruhinya. Jakarta Rineka Cipta, 2010. Sobry, M, "Reaktualisasi Strategi Pendidikan Islam: Ikhtiar Mengimbangi Pendidikan Global”, Ulumuna Jurnal Studi Keislaman Vol. 17, No. 2, December, 2013.

Sugiyono, Metode Penelitian Kombinasi (Mixed Methods) Vol. 1, Bandung: Alfabeta, 2011.

Surakhmad, Winarno, Dasar dan Tehnik Interaksi Mengajar dan Belajar.Bandung: Tarsito, 1973. Syah, M, Psikologi Pendidikan dengan Pendekatan Baru. Bandung: PT Remaja Rosdakarya, 2011. Syurfah, Ariani, Multifle Intelligences for Islamic Teaching (Panduan Melejitkan Kecerdasan Majemuk Anak Melalui Pengajaran Islam), Bandung: Syamil Publishing, 2007. 
MADANIA Vol. 22, No. 2, Desember 2018

Uno, Hamsah B, Profesi Kependidikan: Problema, Solusi, dan Reformasi Pendidikan di Indonesia Vol. IV; Jakarta: Bumi Aksara, 2009.
Zamroni, Pendidikan Masa Depan. Yogyakarta: Bigraf Publising, 2010. 